\title{
Bittersweet (Tax) Symphony
}

\section{Li Shao Wu}

\section{Introduction}

The increased globalization has given rise to many new opportunities for companies to conduct their business. Companies reach out, far beyond the boundaries of their home state. However, conducting business abroad leads to a plethora of tax rules which a company should take into account. They are no longer limited to the tax legislation of their home state, but the companies should also adhere to the tax laws applicable in the state where they conduct their business. This may lead to the undesired effect of double taxation. In order to prevent this effect, many countries have signed tax treaties through which they allocate taxing. The interface of a variety of domestic legislations and tax treaties leads to higher compliance costs to companies, but many companies have been able to utilize the rules to severely limit their tax liability.

As the financial crisis has left its mark upon the world, Nongovernmental organisations (NGOs) are calling for companies to pay their fair share of taxes. NGOs are publishing reports condemning the tax structures employed by companies to limit their tax liability resulting in a very low effective tax rate on their business income. This has led to negative media attention to well-known companies like Google and Starbucks. But it is not just the companies that have come under scrutiny, several countries have received negative attention as well. For instance, The Netherlands and Ireland have been criticized for their roles in tax planning structures.

Tax planning issues, however, are not limited to developed countries. Action Aid, an NGO which aims to protect human rights and combat poverty $^{1}$, has released several reports on companies shifting profits away from African source states. ${ }^{2}$ This article serves to give the reader an overview of the tax structure discussed in the 'Sweet Nothings'

1 http://www.actionaid.org.uk.

2 E.g. Calling Time. Why Sabmiller should stop dodging taxes in Africa, Action Aid 2012, available at: http://www.actionaid.org.uk/taxjustice/calling-time-the-research. 
report published by Action Aid in $2013 .{ }^{3}$ The primary focus will be how specific domestic rules and tax treaties lowers the effective tax rates. Furthermore, I will discuss recent developments made by the OECD on base erosion and profit shifting (BEPS).

\section{The Sugar-Coated Tax Structure}

Like many other tax planning structures, such as the 'double Irish with a Dutch sandwich' structure ${ }^{4}$, the tax structure employed by Zambia Sugar benefits from of peculiarities in various domestic legislations and tax treaties. ${ }^{5}$ In many cases, more than two countries are involved in the tax structure. ${ }^{6}$ The same can be said of the tax structure employed by Zambia Sugar as detailed in the Sweet Nothings report. Further on in this paragraph I will look at the Zambian tax system in general. Then I will discuss through which means this structure shifts profits away from Zambia and look at some specific tax incentives given by Zambia. The following figure 1 shows the Zambia Sugar tax structure. ${ }^{7}$

3 M. Lewis, Sweet Nothings. The human cost of a British sugar giant avoiding taxes in southern Africa, Action Aid: 2013. Available at: http://www.actionaid.org/publications/sweet-nothings.

4 H.T.P.M. van den Hurk, 'Starbucks versus the People', in 68 Bull. Intl. Taxn. 1 (2014), Journals IBFD.

5 For more tax planning techniques, see: R. Rohatgi, Basic International Taxation. Volume 2: Practice, London, United Kingdom: BNA International Inc. 2007, p. 4 et seq.

6 This is also the situation in the structure employed by e.g. Starbucks which involves The Netherlands, Ireland, Bermuda and the US, detailed in: H.T.P.M. van den Hurk, 'Starbucks versus the People', 68 Bull. Intl. Taxn, 1 (2014), Journals IBFD.

7 M. Lewis, Sweet Nothings. The human cost of a British sugar giant avoiding taxes in southern Africa, Action Aid 2013, p. 9. 
Figure 1. Zambia Sugar Tax Structure

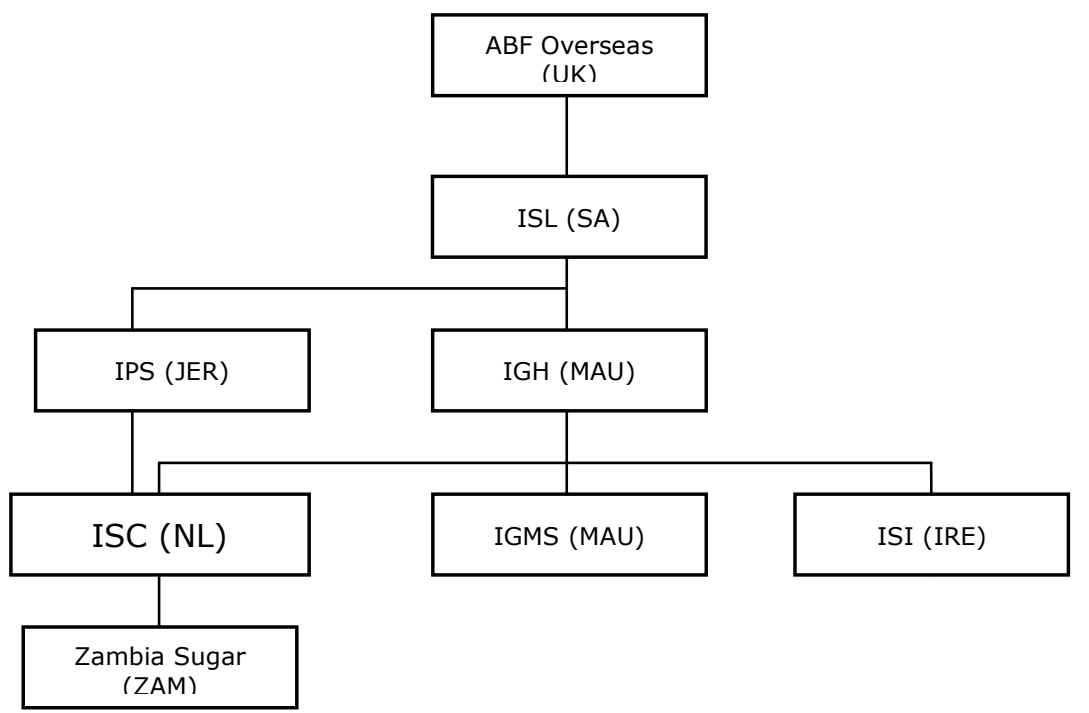

\subsection{The Zambian tax system}

Business income that is sourced or deemed to be sourced in Zambia will be subject to tax in Zambia. The dividend and interest payments to companies resident in Zambia will also be taxed in Zambia. The general corporate income tax (CIT) rate in Zambia is 35\%, which is similar to that of the United States. ${ }^{8}$ Compared to European countries, the Zambian CIT rate is slightly higher. ${ }^{9}$ However, Zambia does provide for several tax incentives, for example, through a lower tax rate. This is the case for mining operations which have a corporate income tax rate of

8 Federal top rate in the US is 35\%, see: United States - Key Features, Country Key Features IBFD (accessed 6 May 2014).

9 In 2013, the average (top) CIT rate in Europe was 23,5\%, see: Eurostat, Taxation trends in the European Union. Data for the EU Member States, Iceland and Norway, Luxembourg (LU): Publications Office of the European Union 2013, p. 36-38. Available at http://ec.europa.eu/taxation customs/taxation/gen info/economic anal ysis/tax structures/index en.htm. 
$30 \%$ and farming and agro-processing even has a tax rate of only $10 \% .^{10}$

Non-resident companies are only taxed if the income they receive is sourced or deemed to be sourced within Zambia. If that is the case, Zambia will levy a withholding tax on dividends, interest payments and will levy a withholding tax on management and consultancy fees paid to the non-resident company. ${ }^{11}$ In such a case, that withholding tax will be a final tax.

Taking into account the aforementioned aspects of the Zambia corporate income tax system, it seems odd that, according to Action Aid, Zambia Sugar pays next to no taxes in Zambia between 2008 and 2010. So how is this possible?

\subsection{How to avoid taxes?}

As stated before, Zambia generally levies taxes on business income sourced within Zambia. Therefore, if management and consultancy fees are paid to a non-resident company, Zambia will levy a withholding tax. ${ }^{12}$ The tax rate of the withholding tax is $20 \%{ }^{13}$ according to the Zambia Income Tax Act, which is a final tax.

As part of the tax structure, Zambia Sugar pays a lot of management and consultancy fees to Illovo Sugar Ireland (ISI). Under the domestic law Zambia Sugar would have to withhold taxes, however this is negated by the tax treaty between Zambia and Ireland which has been in force since 1973. According to that tax treaty, the taxing rights on professional services is exclusively allocated to the state of residence of the service provider. ${ }^{14}$

The result of the application of the tax treaty is that no tax is levied in Zambia on the management and consultancy fees paid by Zambia Sugar. The taxing rights are exclusively allocated to the resident state of the service provider, i.e. ISI. On the other hand, the payment does qualify as operating expenses which are deductible in Zambia. Through

10 K. Munyandi, Zambia - Corporate Taxation sec. 1.6.1., Country Surveys IBFD (accessed 6 May 2014).

11 K. Munyandi, Zambia - Corporate Taxation sec. 1.6.2., Country Surveys IBFD (accessed 6 May 2014).

12 Section 82a(a) Zambia Income Tax Act.

13 Website of the Zambia Revenue Authority:

https://www.zra.org.zm/commonHomePage.htm?viewName=Withholdin gTax.

14 Article XII Tax Treaty Ireland - Zambia. 
the payment of management and consultancy fees, the profits of Zambia Sugar in Zambia is reduced. ${ }^{15}$ ISI goes on to make payments to Illovo Sugar Ltd., established in South Africa, and to an Illovo subsidiary established in Jersey. Therefore the Irish company retains little of its profits. ${ }^{16}$

As of 2011 Zambia Sugar has also made payments to Illovo Group Marketing Services (IGMS) established in Mauritius. According to the Sweet Nothings report, IGMS the corporate income tax rate in Mauritius is only $3 \%$. These payments, which are labelled as 'export agency commissions' serve to further reduce the profits in Zambia. ${ }^{17}$

\subsection{Dublin dog-leg}

In order to expand their business, Zambia Sugar required a loan of $\$ 70$ million. This loan was extended to the company by ISI. However, the Irish company did not have sufficient capital on its own to supply the loan and therefore had to borrow the same amount from two commercial banks. The loans are provided to the Irish company through branches of the commercial banks in the United Kingdom. ${ }^{18}$ So even though the loan is paid from a Zambian bank account to Zambia Sugar and denominated in the Zambian currency, the loan was provided through the United Kingdom and Ireland.

Because the loan was provided to Zambia Sugar by ISI, the tax treaty between Zambia and Ireland applies. Pursuant to the tax treaty, Zambia may not levy a withholding tax on the interest payments made to ISI. ${ }^{19}$ In contrast, if the loan was directly provided by the United Kingdom branches of the commercial banks, the treaty between the United Kingdom and Zambia would be applicable. Under the tax treaty ZambiaUnited Kingdom, Zambia would be allowed to levy a withholding tax of maximum $10 \%$ on the interest payment. ${ }^{20}$ Furthermore, if the loan was

$15 \mathrm{M}$. Lewis, Sweet Nothings. The human cost of a British sugar giant avoiding taxes in southern African, Action Aid 2013, p. 18.

16 Id., p. 18-19.

17 Id., p. 19-20.

18 Id., p. 22-23.

19 The treaty prevents withholding taxes on interest payments to the resident of the other contracting state who is beneficially entitled to the interest, see Art. IX Tax Treaty Zambia-Ireland.

20 Art. 12, para. 1 and para. 3, Tax Treaty Zambia-United Kingdom 1972. Under the new treaty, which was signed on 5 February 2014 but has not yet entered into force, no withholding tax may be levied if the 
provided to Zambia Sugar from the head offices of the banks, which are established in the United States and South Africa respectively ${ }^{21}$, then Zambia would likely be able to levy $15 \%{ }^{22}$ of withholding tax on the interest payments. The reason for this is that Zambia does not have a tax treaty with the United State thus their taxing rights are not limited. With regard to the South African bank, there is a tax treaty, but the taxing right is allocated to the resident state of the debtor, which is Zambia Sugar. ${ }^{23}$ Through so-called 'treaty shopping' Zambia Sugar does not have to withhold any tax on the interest payments, while on the other hand the payments are deductible because they are real costs to the company.

Subsequently, ISI will have to pay interest to the two commercial banks. Because the loan was extended through United Kingdom branches, the tax treaty between Ireland and the United Kingdom applies. The taxing right on interest payments is allocated to the state of residence of the beneficiary of the payment pursuant to that tax treaty. ${ }^{24}$ The end result is that no withholding tax is levied on the interests payments which helped to keep the interest on the loan low. ${ }^{25}$

\subsection{Optimal profit distribution}

An important part of any tax planning structure is the distribution of profits. Many United States companies have to deal with locked out profits because their foreign profits are taxed when they are remitted to the United States, e.g. in the form of dividends. ${ }^{2627}$ In order to reward

recipient is a resident of the other Contracting State and is mentioned in art. 11, para. 3, subsection a, Tax Treaty Zambia-United Kingdom 2014. $21 \mathrm{M}$. Lewis, Sweet Nothings, The human cost of a British sugar giant avoiding taxes in southern Africa, Action Aid 2013, p. 22-23.

22 According to the website of the Zambia Revenue Authority:

https://www.zra.org.zm/commonHomePage.htm?viewName=Withholdin gTax.

23 Art. XII, para. 5, Tax Treaty Zambia-South Africa.

24 Art. 12(1) Tax Treaty United Kingdom-Ireland.

$25 \mathrm{M}$. Lewis, Sweet Nothings. The human cost of a British sugar giant avoiding taxes in southern Africa, Action Aid 2013, p 22-23.

26 P.R. McDaniel, H.J. Ault \& J.R. Repetti, Introduction to United States International Taxation, The Hague (NL): Kluwer Law International 2005, p. 113 et seq. 
shareholders, it is not uncommon for US companies to issue bonds in order to avoid repatriating foreign profits. ${ }^{28}$ However, Zambia Sugar manages to distribute profits without attracting high tax rates.

Until 2007, the immediate parent company of Zambia Sugar was ISI. ${ }^{29}$ Although the withholding tax rate on dividend distributed by a Zambian company is $15 \%{ }^{30}$, which is a final tax, not tax will be levied by Zambia. Because ISI is established in Ireland, the tax treaty between Zambia and Ireland allocates the taxing right on dividend payments to the resident state of the recipient. ${ }^{31}$ The immediate parent company of ISI is Illovo Group Holdings (IGH) which is established in Mauritius. Due to the lack of a tax treaty between Ireland and Mauritius, ISI will have to withhold $20 \%$ dividend tax upon profit distribution. ${ }^{32}$ The remaining profits will be further taxed in Mauritius at a $3 \%$ rate. ${ }^{33}$ From a tax planning point of view this is considered to be a bad tax planning structure. Tax planning has been defined as "a tax-driven proactive arrangement of a person's affairs to minimise his tax results" which would "normally be optimised when the after-tax profit is maximised" ${ }^{34}$ Therefore a source state taxation of $20 \%$ in Ireland and further taxation of $3 \%$ in Mauritius is undesirable.

In 2007 the shares of Sugar Zambia were transferred from ICI to the Dutch Illovo Sugar Coöperatief U.A. (ISC). ${ }^{35}$ Because ISC is treaty

27 For a full overview of this tax planning structure see: H.T.P.M. van den Hurk, 'Starbucks versus the People', 68 Bull. Intl. Taxn. 1 (2014), Journals IBFD.

28 For an example see http://www.bloomberg.com/news/2014-0429/apple-returns-to-bond-market-to-scale-biggest-borrowers-

ranks.html.

29 M. Lewis, Sweet Nothings. The human cost of a British sugar giant avoiding taxes in southern Africa, Action Aid 2013, p. 25.

30 See:

https://www.zra.org.zm/commonHomePage.htm?viewName=Withholdin gTax.

31 Taxing rights are allocated to the state of resident of the recipient pursuant to Art. VIII(1) Tax Treaty Zambia-Ireland.

32 O. Ostaszewska, Ireland - Corporate Taxation sec. 6.3.1., Country Surveys IBFD (accessed 9 May 2014).

$33 \mathrm{M}$. Lewis, Sweet Nothings. The human cost of a British sugar giant avoiding taxes in southern Africa, Action Aid 2013, p. 19.

34 R. Rohatgi, Basic International Taxation. Volume 2: Practice, London (UK): BNA International Inc. 2007, p. 1.

$35 \mathrm{M}$. Lewis, Sweet Nothings. The human cost of a British sugar giant avoiding taxes in southern Africa, Action Aid 2013, p. 25-26. 
entitled, the tax treaty between The Netherlands and Zambia is applicable to the dividends paid by Zambia Sugar. ${ }^{36}$ Pursuant to the tax treaty the withholding tax rate on dividend payments is maximized at $15 \%$, but this is lowered to $5 \%$ if the recipient of the payment is wholly or partly divided into shares and holds directly at least $25 \%$ of the capital of the company paying the dividend. ${ }^{37}$ As a result Zambia may only levy $5 \%$ withholding tax on the dividend payment. ISC will not be taxed on the dividend it receives in The Netherlands because it can apply the participation exemption. ${ }^{38}$ The application of the participation exemption ensures that the profits distributed by a subsidiary will not be taxed at the level of the parent company. ${ }^{39}$ If the profits are further distributed by ISC to ISH, which is established in Mauritius, ISC does not have to withhold any dividend tax. The reason for this is because ISC, as a cooperative, is under no obligation to withhold dividend tax. ${ }^{40}$ In 2012 a new provision ${ }^{41}$ was introduced by the Dutch legislator pursuant to which a cooperative is forced to withhold dividend tax if certain conditions are met. This provision will be discussed later on.

\subsection{Zambian tax incentives}

Additionally, there are two specific tax incentives granted to Zambia Sugar which further serve to reduce their tax burden in Zambia. Firstly, the entire profits of Zambia Sugar are considered to be derived from farming operations. As a result of this, instead of the general CIT rate of $35 \%$ the special rate for farming and agro-processing of $10 \%{ }^{42}$ applies. Even though a large part of the profit is derived from producing sugar

36 H.T.P.M. van den Hurk \& J.T.L. Nillesen, 'Netherlands Cooperatives as Intermediate Holding Companies in International Investment Structures', 66 Bull. Intl. Taxn. 12 (2012), Journals IBFD, p. 659.

37 Art. 10(1) and (2) Tax Treaty Zambia-The Netherlands.

38 Art. 2(1)(b) and art. 13(1) and (2) Dutch CIT Act (Wet op de vennootschapsbelasting 1969).

39 Art. 13 Dutch CIT Act (Wet op de vennootschapsbelasting 1969)

40 H.T.P.M. van den Hurk \& J.T.L. Nillesen, 'Netherlands Cooperatives as Intermediate Holding Companies in International Investment Structures', 66 Bull. Intl. Taxn. 12 (2012), Journals IBFD, p. 659 et seq. 41 Art. 1(7) Dutch Dividend Tax Legislation (Wet op de dividendbelasting 1965).

42 K. Munyandi, Zambia - Corporate Taxation sec. 1.6.1., Country Surveys IBFD (accessed 17 May 2014). 
and not farming. ${ }^{43}$ Secondly, the Zambian Development Agency (ZDA) may grant tax incentives to companies. If the ZDA declares that a company has made an investment in a priority sector, the tax rate will be $0 \%$ for the first five years. ${ }^{44}$ It is questionable whether or not these additional incentives have the effects the Zambian legislator had in mind. Through foreign investment more jobs are created for the local population, however the structure detailed in this paragraph shows that much of the business profits of Zambia Sugar leave the country to tax havens. ${ }^{45}$ These additional tax incentives will not be further discussed in this article.

\section{Tackling Tax Planning}

As shown above, the structure employed by Zambia Sugar leads to a loss in tax revenue for Zambia. The revenue loss is caused, in part, by bilateral tax treaties which Zambia has concluded with Ireland and The Netherlands, even though one of the important goals of a tax treaty is to prevent fiscal evasion. ${ }^{46}$ In this paragraph I will discuss recent (re)negotiations of tax treaties. I will also look at the Dutch perspective on cooperatives and treaty abuse.

\section{1 (Re)negotiating tax treaties}

Recently Zambia and Ireland have started negotiations to revise their 1971 income tax treaty. ${ }^{4748}$ The main issue with the current tax treaty is the allocation of the exclusive taxing rights on dividend payments, interest payments and payments for professional services to the resident state of the recipient. ${ }^{49}$ In order to mitigate the problems caused by these treaty provisions, I believe that the new treaty will

43 M. Lewis, Sweet Nothings. The human cost of a British sugar giant avoiding taxes in southern Africa, Action Aid 2013, p. 27-28.

44 K. Munyandi, Zambia - Corporate Taxation sec. 1.7.3., Country Surveys IBFD (accessed 17 May 2014).

45 Veronica Daurer, Tax treaties and developing countries, Alphen aan den Rijn (NL): Kluwer Law International 2014, p. 35.

46 Id., p. 28 et seq.

47 Ireland: Zambia - Revision to tax treaty between Ireland and Zambia - negotiations (13 Mar. 2014), News IBFD.

48 Ireland; Zambia - Treaty between Ireland and Zambia initialled (17 Mar. 2014), News IBFD.

49 Art. VII, IX and XIII Tax Treaty Zambia-Ireland. 
include at least a shared taxing right on these payments. As a result Zambia will be allowed to levy at least some tax on the payments made to Irish residents. though it remains unclear what the ultimate tax treaty will cover and how the taxing rights will be allocated.

Furthermore, the tax treaty between Zambia and Mauritius entered into force on June 4 2012. Under this treaty the source state may levy (limited) withholding taxes on dividends ${ }^{50}$, royalties ${ }^{51}$ and interest payments ${ }^{52}$. However, professional services are taxable only in the resident state of the service provider unless he has a fixed base regularly available to him in the source state. If that is the case, the source state may only tax the income that is attributable to that fixed base. ${ }^{53}$

\section{Interpretation of tax treaties}

Part of the profits of Zambia Sugar are shifted to other countries because they are denominated as management fees to Ireland or export agency commissions to Mauritius. ${ }^{54}$ Pursuant to the relevant tax treaties ${ }^{55}$, these payments are generally not subject to withholding tax in Zambia. However, legal text can be interpreted in various ways as there is no single correct way of interpretation. ${ }^{56}$ In this regard, the Vienna Convention on the Law of Treaties (VCLT) gives some guidance as to how treaties should be interpreted. Treaties have to be interpreted in "good faith and in accordance with the ordinary meaning to be given to the terms of the treaty in their context and in the light of its object and purpose". ${ }^{57}$ When determining the context of a treaty the text, preamble and annexes of a treaty are important, amongst other elements. ${ }^{58}$ But what is the influence of Model Conventions, such as the OECD Model Tax Convention (OECD Model Convention) and the United Nations Model Double Taxation Convention (UN Model Convention), and

50 Art. 10(1) and (2) Tax Treaty Zambia-Mauritius.

51 Art. 12(1) and (2) Tax Treaty Zambia-Mauritius.

52 Art. 11(1) and (2) Tax Treaty Zambia-Mauritius.

53 Art. 13 Tax Treaty Zambia-Mauritius.

$54 \mathrm{M}$. Lewis, Sweet Nothings. The human cost of a British sugar giant avoiding taxes in southern Africa, Action Aid 2013, p. 16 et seq.

55 i.e. Tax Treaty Zambia-Ireland (1973) and Tax Treaty ZambiaMauritius.

56 S.A. Rocha, Interpretation of Double Taxation Conventions. General Theory and Brazilian Perspective, Alphen aan den Rijn (NL): Kluwer Law International 2009, p. 71 et seq.

57 Art. 31(1) VCLT.

58 Art. 31(2) VCLT. 
their commentaries when interpreting a tax treaty? The OECD Model Convention is not intended to be binding nor are the commentaries to the Model Convention. ${ }^{59}$ However, the OECD commentaries is often regarded as 'soft law'. ${ }^{60}$ The OECD Model Convention 2010 also notes that the commentaries are not meant to have a binding effect, but they can assist in order to interpret a tax treaty. ${ }^{61}$

\section{Service permanent establishment}

Because there is no single correct way to interpret a tax treaty, the way Zambia interprets its treaties may have an effect on the allocation of taxing rights. Both the Zambia-Mauritius and the Zambia-Ireland tax treaties contain provisions regarding the permanent establishment (PE). ${ }^{62}$ The approach of the OECD has been that services provided within the territory of the source state by a non-resident taxpayer does not constitute a PE. ${ }^{63}$ This is specifically stated in the OECD commentaries on article 5 of the OECD Model. ${ }^{64}$ Therefore services provided by a non-resident enterprise are taxed only in the state of residence. The OECD does note that some states may want to tax those services, thus the OECD has suggested a services PE provision in its commentary. ${ }^{65}$ On the other hand, the UN Model Convention has included the service PE since 1980 which stipulates that "the term 'permanent establishment' also encompasses the furnishing of services, including consultancy services, by an enterprise through employees or other personnel engaged by the enterprise for such purpose (...)" ${ }^{66}$ This provision was intended to be a clarification of the OECD Model definition

59 D.A. Ward, J.F. Avery Jones, L. De Broe, et al., The Interpretation of Income Tax Treaties with Particular Reference to the Commentaries on the OECD Model, Kingston (CA): International Fiscal Association 2005, p. 15 et seq.

60 Id., p. 38 et seq.

61 OECD (2012), 'Introduction', in Model Tax Convention on Income and on Capital 2010 (Full Version), OECD Publishing, point 29.

62 Art. III Tax Treaty Zambia-Ireland and art. 5 Tax Treaty ZambiaMauritius.

63E. Reimer, N. Urban and S. Schmid, Permanent Establishments. A Domestic Taxation, Bilateral Tax Treaty and OECD Perspective, Alphen aan den Rijn (NL): Kluwer Law International 2012, p. 113 et seq.

64OECD (2012), 'Commentary on Article 5: Concerning the definition of permanent establishmen', in Model Tax Convention on Income and on Capital 2010 (Full Version), OECD Publishing, point 42.11.

65 Id., point 42.23.

66 Art. 5(3)(b) UN Model Convention. 
of the $\mathrm{PE}^{67}$ rather than a deviation. ${ }^{68}$ In practice the OECD seems reluctant to adopt the service $P E$, noting difficulties with administration and compliance. ${ }^{69}$ As a result, the OECD approach generally requires a place of business in the source state in order to determine that there is a PE where the UN approach abandons geographical fixation. ${ }^{70}$

If Zambia would take the approach that the furnishing of services can be considered to be a PE, the tax structure employed by Zambia Sugar may lead to a very different result. The management services provided by ISI to Zambia Sugar would be considered to be a service PE. The payments made in connection to these services are therefore attributable to the service PE in Zambia and therefore taxed in Zambia. It remains unclear whether the services are actually rendered in Zambia or not. However, Zambia is free to interpret the tax treaty in such a way that the presence in the source state is not necessary and the fact that the fees are paid by Zambia Sugar to ISI is sufficient to consider the existence of a service PE. ${ }^{71}$ For instance, India has stated that it does not agree with the interpretation "that taxation does not extend to services performed outside the territory of a state". ${ }^{72}$ Through this interpretation the management fees are taxed in Zambia instead of Ireland because the ISI service PE is established in Zambia. Consequently, Zambia may levy withholding tax on the payments.

Similarly, the export agency services provided by IGMS can also be considered to be a service PE. As the export agency commissions are directly attributable to the service $P E$, these payments are taxable in Zambia. By including the furnishing of services in the PE concept Zambia would be able to (partly) mitigate the shifting of profits.

67 Art. 5(1) OECD Model Convention.

68 E. Reimer, N. Urban and S. Schmid, Permanent Establishments. A Domestic Taxation, Bilateral Tax Treaty and OECD Perspective, Alphen aan den Rijn (NL): Kluwer Law International 2012, p. 113.

69 OECD (2012), 'Commentary on Article 5: Concerning the definition of permanent establishment', in Model Tax Convention on Income and on Capital 2010 (Full Version), OECD Publishing, point 42.12.

70 E. Reimer, N. Urban and S. Schmid, Permanent Establishments. A Domestic Taxation, Bilateral Tax Treaty and OECD Perspective, Alphen aan den Rijn (NL): Kluwer Law International 2012, p. 115.

71 Veronica Daurer, Tax treaties and developing countries, Alphen aan den Rijn (NL): Kluwer Law International 2014, p. 70.

72 OECD (2012), 'Positions on article 5 (Permanent Establishment) and its commentary', in Model Tax Convention on Income and on Capital 2010 (Full Version), OECD Publishing, point 38, 


\subsection{A Dutch perspective}

The role of The Netherlands in the Zambia Sugar tax structure is the dividend distributions of Zambia Sugar through ISC. In a report published by the International Bureau of Fiscal Documentation (IBFD) it was noted that the tax treaty between Zambia and The Netherlands lacks any anti-avoidance measures and beneficial ownership rules. ${ }^{73}$ In response to this report the Dutch State Secretary of Finance has stated that the lack of anti-avoidance measures and beneficial ownership rules stems from the fiscal treaty policy at the time the treaty was signed. However, The Netherlands is willing to renegotiate with treaty partners to include anti-avoidance measures in the tax treaties. ${ }^{74}$ With respect to Zambia, The Netherlands have proposed to update the existing tax treaty. ${ }^{75}$ The treaty has already been renegotiated. ${ }^{76}$ Although the result has not been published, the treaty will likely include anti-avoidance measures to avoid treaty abuse. But even with a new anti-abuse rule, this will likely not bring any changes because the inclusion of the Dutch cooperative in the structure is not viewed as treaty abuse. Zambia Sugar employs the beneficial treatment of the cooperative instead of actually abusing the tax treaty. According to The Netherlands a clear distinction must be made between treaty abuse and tax avoidance which is in conflict with domestic legislation. ${ }^{77}$

Cooperative: treaty abuse?

Treaty abuse is primarily associated with treaty shopping which has been defined as "(...) a situation in which a person who is not entitled to the benefits of a tax treaty makes use - in the widest meaning of the word - of an individual or legal person in order to obtain those treaty

73 Onderzoek belastingverdragen met ontwikkelingslanden, FEZ/IM354/DDE 2013), available at http://www.rijksoverheid.nl/documenten-enpublicaties/brieven/2013/08/30/onderzoek-belastingverdragen.html. 74 NL: Parliamentary Papers II 2012-2013, 25 057, no. 60, p. 2-3. 75 NL: Parliamentary Papers II 2012-2013, 25 057, no. 60, p. 24. 76 Netherlands; Zambia - Treaty between Netherlands and Zambia negotiations (06 May 2014), News IBFD.

77 NL: Notitie Fiscaal Verdragsbeleid 2011 (Memorandum tax treaty policy 2011), p. 25. 
benefits that are not available directly". ${ }^{78}$ However, treaty abuse can cover more than just treaty shopping, and implies that there is a 'proper use' of tax treaties. In order to identify this there must be some sort of common understanding on treaty abuse which there is not. ${ }^{79} \mathrm{I}$ will focus on treaty shopping.

The Dutch cooperative ISC is included in the Zambia Sugar tax structure in order to benefit from its treaty entitlement through which the Zambian dividend withholding tax is lowered to $5 \% .{ }^{80}$ This structure is not meant to specifically gain the treaty benefits provided by the tax treaty, but the benefits the Dutch cooperative offers. In particular the lack of dividend withholding tax in The Netherlands upon profit distribution by the cooperative makes it an attractive legal form. Therefore it is my opinion that this structure is not treaty abuse and as a consequence any anti-avoidance measure targeting treaty abuse introduced by The Netherlands and Zambia in the renewed tax treaty will not sort any effect.

\section{Abuse of Dutch cooperatives}

The Dutch legislator has noted the possibility to abuse cooperatives in order to avoid Dutch dividend withholding tax or foreign taxes and has therefore introduced an anti-abuse measure in domestic legislation. ${ }^{81}$ Pursuant to the anti-abuse measure cooperatives are required to withhold Dutch dividend tax in certain abusive situations. ${ }^{82}$ This would be the case if a non-Dutch entity includes a Dutch cooperative, without any genuine significance, in a business structure in order to avoid Dutch dividend withholding tax. The same is true if the non-Dutch entity with a non-Dutch subsidiary includes a Dutch cooperative, without any genuine significance, in a business structure with the intention to avoid foreign taxation of another entity. ${ }^{83}$ In determining whether the cooperative is liable for taxation a distinction is made between the situation where the cooperative is part of the business assets of the

78 Stef van Weeghel, The improper use of tax treaties. With particular reference to the Netherlands and the United States, London (UK): Kluwer Law International Ltd. 1998, p. 119.

79 H. David Rosenbloom, 'Tax Treaty Abuse: Policies and Issues', in 15 Law \& Pol'y Int'l Bus. 763 (1983).

80 Art. 10(1) and (2) Tax Treaty Zambia-The Netherlands.

81 Art. 1(7) Dutch dividend tax legislation (Wet op de dividendbelasting 1965).

82 NL: Parliamentary Papers II, session year 2011-2012, 33 003, no. 3, p. $16-17$.

83 Id., p. 111-112. 
member (company structure) and when it is not (portfolio investment structure).

In case of a portfolio investment structure the cooperative can have an unlimited liability for dividend withholding tax if certain conditions are met. The first condition is that the motive to include the cooperative in the structure is tax avoidance. Whether this is the case is assessed by comparing the situation including the cooperative to the situation excluding the cooperative in the structure. If the structure, excluding the cooperative, does not lead to a higher dividend withholding tax claim or foreign tax claim there is no avoidance motive. ${ }^{84}$ Secondly, the cooperative should have no genuine economic significance. According to the State Secretary of Finance this should also be determined in line with case law of the European Court of Justice in which 'wholly artificial arrangements ${ }^{\prime 85}$ are discussed. ${ }^{86}$ In practice, if the structure concerns a company structure, economic significance is generally attributed to the cooperative. ${ }^{87}$ However, in case of portfolio investment structures it is less likely that a cooperative has any actual functions. Therefore it is more likely that, in case of portfolio investment structures, the use of cooperatives would be qualified as an abusive situation and as a result the cooperative will be forced to withhold dividend tax. ${ }^{88}$ If there is an abusive situation regarding a company structure, the cooperative may be required to withhold dividend tax, although the amount is limited. ${ }^{89}$

If a structure is regarded as abusive, the membership rights will be treated as shares and the cooperative will be deemed to be an entity whose capital is divided into shares. ${ }^{90}$ In the Zambia Sugar structure the question is whether the inclusion of the cooperative is an abusive situation. If the cooperative is not included in the structure, Zambia

84 W.W. Monteiro \& J. van Gool, 'Misbruik van coöperaties; het is duidelijk dat het niet duidelijk is', in NTFRA 2013/26.

85 E.g. ECJ 12 September 2006, Case C-196/04 (Cadburry Schweppes). 86 NL: Parliamentary Papers II, session year 2011-2012, 33 003, no. 10 , p. 30.

87 H.T.P.M. van den Hurk \& J.T.L. Nillesen, 'Netherlands Cooperatives as Intermediate Holding Companies in International Investment Structures', 66 Bull. Intl. Taxn. 12 (2012), Journals IBFD, p. 661.

88 Id., p. 662.

89 For further reference see H.T.P.M. van den Hurk \& J.T.L. Nillesen, 'Netherlands Cooperatives as Intermediate Holding Companies in International Investment Structures', 66 Bull. Intl. Taxn. 12 (2012), Journals IBFD, p. 659-663.

90 Art. 1(7) Dutch dividend tax legislation (Wet op de dividendbelasting 1965). 
would be entitled to withhold its domestic withholding tax rate of $20 \%$ on dividend payments by Zambia Sugar to its parent company established in a tax haven. Because the dividend payments flow through the cooperative, the Zambian dividend withholding tax rate was lowered to $5 \%$ thereby saving Zambian taxes. As the Dutch anti-abuse measure states that the cooperative has to withhold dividend tax if Dutch dividend withholding tax or foreign taxes is avoided through the use of a cooperative, I believe that it is likely that ISC will be forced to withhold $15 \%$ Dutch dividend tax. ${ }^{91}$ As a result of this, the effective tax rate will rise which is undesirable from a tax planning point of view. ${ }^{92}$ However, if ISC has a tax ruling the cooperative will likely not have to withhold dividend tax for the time being because the State Secretary of Finance has stated that no change of the ruling policy was intended and the existing rulings will be respected. ${ }^{93}$

\section{Treaty Abuse: The OECD Approach}

In this article I have focussed on the tax structure employed by Zambia Sugar through which profit is shifted from Zambia to tax havens such as Mauritius and Jersey. However there are many different tax structures which serve to keep the effective tax rate of multinational companies as low as possible. In response, the OECD has published its BEPS action plan ${ }^{94}$ in order to combat tax planning. In this paragraph I will specifically focus on the developments with respect to treaty abuse.

\subsection{OECD BEPS action plan}

The OECD has published its BEPS action plan in response to the current practice of multinational companies to severely limit their tax burden. As a result of this practice by multinational companies, government lose revenue which have to be compensated by increasing the tax burden for individual taxpayers. Local businesses are also harmed because they do

91 Art. 5 Dutch dividend tax legislation (Wet op de dividendbelasting 1965).

92 R. Rohatgi, Basic International Taxation. Volume 2: Practice, London (UK): BNA International Inc. 2007, p. 1.

93 NL: Parliamentary Papers II, session year 2011-2012, 33 003, no. 10 , p. 30.

94 OECD (2013), Action Plan on Base Erosion and Profit Shifting, OECD Publishing. Available at http://dx.doi.org/10.1787/9789264202719-en. 
not possess the possibilities to limit their tax burden in the way multinational companies can. ${ }^{95}$

In order to combat base erosion and profit shifting, the OECD has formulated several action plans. Action plan 6 targets the issue of treaty abuse which has been noted by the OECD as one of the most important sources of BEPS concerns. ${ }^{96}$ These concerns stem from the development of schemes in which e.g. conduit companies in third countries are interposed in a bilateral framework. ${ }^{97}$ The OECD intends to develop model treaty provisions and recommendations on the design of domestic rules to prevent treaty abuse. Furthermore the OECD intends to clarify that tax treaties are "not intended to be used to generate double non-taxation". ${ }^{98}$ On 14 March the OECD released the public discussion draft on BEPS action 6.

\subsection{Discussion draft on treaty abuse}

In the discussion draft a distinction is made between the "case where a person tries to circumvent limitations provided by the treaty itself" and the "case where a person tries to circumvent the provisions of domestic tax law using treaty benefits". ${ }^{99}$ I will focus only on the first case which aims to prevent treaty shopping. In the course of the discussion paper the OECD has made three recommendations.

The first recommendation is to include, in the title and preamble of the tax treaties, that the tax treaty is intended to eliminate double taxation and prevent tax evasion and avoidance. ${ }^{100}$ The goal is to ensure that the tax treaty is interpreted in a way which also prevents double nontaxation instead of only eliminating double taxation. ${ }^{101}$ The interpretation will be based on the context of the treaty which flows, amongst others, from the title, preamble and the text of the treaty. ${ }^{102}$ The OECD has already acknowledged in the commentaries on the Model

95 Id., p. 7-8.

96 Id., p. 18-19.

97 Id., p. 18-19.

98 Id., p. 19.

99 OECD (2014), Public Discussion Draft. BEPS Action 6: preventing the granting of treaty benefits in inappropriate circumstances, p. 3. Available at http://www.oecd.org/ctp/treaties/treaty-abuse-discussiondraft-march-2014.pdf.

100 Id., p. 27-29.

101 Id., p. 28.

102 Art. 31(1) VCLT. 
Convention that one of the functions of tax treaties is to prevent tax avoidance. ${ }^{103}$ Nonetheless I believe it is a positive development to specifically mention the purpose of anti-avoidance in the title and preamble of tax treaties, especially because the commentaries are not binding. However, it is questionable whether this actually changes the way countries would interpret the tax treaties.

Secondly, the OECD recommends to include a limitation of benefits (LOB) provision in tax treaties. The LOB provision ensures that a resident of a contracting state is, in principle, only entitled to the full benefits of a tax treaty if he is a 'qualified person'. ${ }^{104}$ The proposed LOB provision further states when a resident is considered to be a qualified person. ${ }^{105}$ Furthermore, residents will be treaty entitled to certain items of income. ${ }^{106}$ However, if a resident is not a qualified person nor has items of income through which he is treaty entitled, he shall regardless be entitled to the benefit of the treaty with respect to a specific item of income, if the "competent authority determines that the establishment, acquisition or maintenance of such person and the conduct of its operations did not have as one of its principal purposes the obtaining of benefits under [the] convention". ${ }^{107}$

Thirdly, the OECD recommends the introduction of a 'main purposes test'. This can be considered to be a general anti-avoidance rule (GAAR) which states that a treaty benefit is denied if "one of the main purposes of any arrangement or transaction that resulted directly or indirectly in that benefit, unless it is established that granting that benefit in these circumstances would be in accordance with the object and purpose of the relevant provisions of this Convention".

It is obvious that the LOB provision and main purposes test intend to prevent treaty abuse. However, this two-step approach will be very burdensome for taxpayers. As noted by the Dutch Association of Tax Advisors it would be undesirable for a taxpayer to go through the LOB provision test and still be denied the treaty benefits under the broadly

103 OECD (2012), 'Commentary on Article 1: Concerning the persons covered by the convention', in Model Tax Convention on Income and on Capital 2010 (Full Version), OECD Publishing, point 7.

104 F.A. Vega Borrego, Limitation of benefit clauses in double tax conventions, The Hague (NL): Kluwer Law International 2006, p. 91 et seq.

105 OECD (2014), Public Discussion Draft. BEPS Action 6: preventing the granting of treaty benefits in inappropriate circumstances, p. 5-6.

106 Id., p. 6-7.

107 Id., p. 7. 
defined main purposes test. ${ }^{108}$ The BIAC also notes that it is undesirable to layer anti-abuse measures and suggest that the OECD either implements a LOB provision or a GAAR. ${ }^{109}$ I agree with this viewpoint as the main goal of tax treaties is to remove obstacles, e.g. double taxation, in order to stimulate the development of economic relations between countries. ${ }^{110}$ Though it is important to deny treaty benefits in abusive situations, it would be too much of a burden for bona fide taxpayers to include a LOB provision and main purpose test and also leads to less legal certainty for tax payers and tax administrations. In the same sense Deloitte (UK and US), EY, and PwC believe that the two pronged test is undesirable and recommend the use of only the LOB provision. Though they believe that the LOB provision should be less restricting because legitimate structures may be denied treaty benefits under the current proposed provision. ${ }^{111}$ KPMG (UK) considers the LOB provision to be flawed as they believe it is an all or nothing test and therefore prefer the GAAR. However, they believe it should be clarified that the "obtaining of a benefit is only one of the main purposes of an arrangement or transaction where it is reasonable to conclude that the transaction would not have been entered into absent the treaty benefits". ${ }^{112}$

Relating to the Zambia Sugar structure, the GAAR and LOB provision aim to prevent treaty benefits to the loan which is provided through Ireland to Zambia Sugar. Due to the treaty between Zambia and

108 OECD (2014), 'Comments of The Dutch Association of Tax Advisors', in Comments received on public discussion draft. BEPS action 6: preventing the granting of treaty benefits in inappropriate circumstances, $\quad$ p. $6 . \quad$ Available http://www.oecd.org/tax/treaties/comments-action-6-prevent-treatyabuse.htm.

109 OECD (2014), 'Comments of BIAC', in Comments received on public discussion draft. BEPS action 6: preventing the granting of treaty benefits in inappropriate circumstances, p. 4.

110 OECD (2012), 'Introduction', in Model Tax Convention on Income and on Capital 2010 (Full Version), OECD Publishing, point 1.

111 For full comments see OECD (2014), Comments received on public discussion draft. BEPS action 6: preventing the granting of treaty benefits in inappropriate circumstances. Available at http://www.oecd.org/tax/treaties/comments-action-6-prevent-treatyabuse.htm.

112 OECD (2014), 'Comments of KPMG LLP (UK)', in Comments received on public discussion draft. BEPS action 6: preventing the granting of treaty benefits in inappropriate circumstances. 
Ireland, Zambian withholding tax is precluded. Through the application of a GAAR or LOB provision it is very possible that treaty benefits are denied and Zambia may levy withholding tax on the interest payments made by Zambia Sugar to ICI, provided that the treaty includes a GAAR and LOB provision. But it is very unlikely that a GAAR will be introduced in the Model Convention next to a LOB provision. It would lead to too much burden and uncertainty for bona fide taxpayers as well as higher compliance costs. In my opinion the best way to target abusive situations is to use specific anti-avoidance rules. However, the LOB provision as it is proposed is too restricted and should be broadened.

\section{Conclusion}

The Zambia Sugar tax structure has shown one of the ways multinational companies can reduce their effective tax rate. The tax revenue of Zambia suffers greatly from this structure. Some of the negative effects can be mitigated by using a different interpretation of the tax treaties Zambia has concluded with Ireland and Mauritius. By including the service $P E$ in the interpretation of permanent establishments Zambia may be able to tax the payments made by Zambia Sugar concerning management fees and export agency commissions. Furthermore, Zambia has been renegotiating their tax treaty with Ireland and The Netherlands. However, in my opinion the use of cooperatives in the Zambia Sugar tax structure is not regarded as treaty abuse because it concerns the benefit of a Dutch legal form. In order to prevent abuse of cooperatives The Netherlands have implemented anti-abuse legislation in its dividend tax legislation.

The OECD has presented their view on treaty abuse and how they will attempt to combat the improper use of tax treaties. In my opinion the proposed LOB provision combined with a GAAR is far too restricting and will increase the burden of taxpayers. There will be less legal certainty and higher compliance cost for legitimate business structures which goes against the goal of tax treaties to stimulate the development of economic relations between countries. It is important to deny treaty benefits in abusive situations, but I believe it is sufficient to include a LOB provision. Although the proposed LOB provision is too restricting and should be broadened in order to prevent bona fide structures to be denied treaty benefits. 